\title{
POTENSI PEMANFAATAN ARANG TULANG AYAM SEBAGAI ADSORBEN LOGAM BERAT CU DAN Cd
}

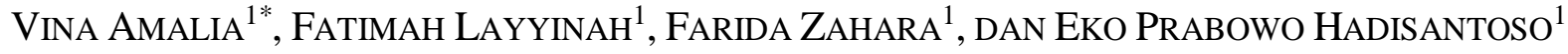 \\ ${ }^{1}$ Jurusan Kimia, Fakultas Sains dan Teknologi, UIN Sunan Gunung Djati Bandung, \\ Jl. A. H. Nasution No. 105 Cibiru Kota Bandung \\ *alamat email korespondensi: vinaamalia@uinsgd.ac.id
}

\begin{tabular}{l}
\hline Informasi Artikel \\
\hline Riwayat Naskah : \\
Diterima pada 26 \\
Mei 2017 \\
Diterima setelah \\
direvisi pada 27 Juni \\
2017 \\
Diterbitkan pada 30 \\
Juni 2017 \\
\\
Kata Kunci: Tulang \\
ayam; arang aktif; \\
adsorpsi; logam Cd; \\
logam Cu.
\end{tabular}

Keywords: Bone chicken; activated carbon; adsorption, metals Cd; Cu metal.

\begin{abstract}
Abstrak/Abstract
Komposisi tulang utamanya mengandung kira-kira $85 \%$ mineral adalah kalsium fosfat, $14 \%$ kalsium karbonat dan $1 \%$ magnesium. Oleh karena itu, serbuk tulang ayam memiliki potensi sebagai adsorben untuk menyerap ion logam berat di lingkungan perariran. Diantara logam berat yang berbahaya bagi lingkungan adalah $\mathrm{Cu}$ dan $\mathrm{Cd}$, yang dihasilkan dari proses industri. Pada penelitian ini dipelajari kemampuan arang aktif dari limbah tulang ayam sebagai material penyerap ion logam tembaga dan kadmium. Faktor-faktor yang berpengaruh terhadap penyerapan logam tembaga oleh arang aktif dipelajari dengan melakukan variasi waktu kontak, konsentrasi larutan dan variasi ukuran partikel dari arang aktif. Konsentrasi tembaga ditentukan dengan menggunakan metode spektrofotometri serapan atom (SSA). Dan karakteristik dari arang tulang ayam yang dihasilkan dilakukan dengan FTIR dan SEM. Penelitian ini memberikan hasil bahwa efisiensi adsorpsi arang aktif tulang ayam terhadap ion logam tembaga dan kadmium meningkat dengan mengingkatnya waktu kontak dan ukuran partikel dan menurun dengan penigkatan konsentrasi. Kapasitas adsorpsi arang aktif tulang ayam terhadap ion logam tembaga dan kadmium meningkat dengan meningkatnya konsentrasi awal ion logam cadmium, waktu kontak dan ukuran partikel.
\end{abstract}

The main bone composition containing approximately $85 \%$ mineral is calcium phosphate, $14 \%$ calcium carbonate and 1\% magnesium. Therefore, chicken bone powder has potential as an adsorbent to absorb heavy metal ions in the aquatic environment. Among the heavy metals that are harmful to the environment is $\mathrm{Cu}$ and $\mathrm{Cd}$, resulting from industrial processes. In this research studied the ability of activated carbon from waste chicken bones as absorbent material metal ions of copper and cadmium. Factors that influence the absorption of copper metal by activated carbon studied by performing a variation of contact time, concentration and particle size variations of activated carbon. Copper concentration was determined using atomic absorption spectrophotometry (AAS). And the characteristics of the resulting carbon chicken bone carried by FTIR and SEM. This study provides results that the efficiency of chicken bone activated charcoal adsorption of copper and cadmium metal ions increases with increasing contact time and particle size and decreases with increasing concentration. Adsorption capacity of activated carbon chicken bone to metal ions of copper and cadmium increased with increasing initial concentration of metal ions cadmium, contact time and particle size.

\section{PENDAHULUAN}

Logam berat memiliki sifat yang toksik, tidak dapat terbiodegradasi, dan dapat terakumulasi dalam rantai makanan. Dengan sifat-sifat tersebut menjadikan keberadaan logam berat di dalam lingkungan sangat berbahaya [1]. Sumber logam berat di lingkungan berasal dari aktivitas manusia, diantaranya kegiatan industri yang secara sengaja atau tidak sengaja membuang limbahnya yang mengandung logam berat ke lingkungan tanpa pengolahan terlebih dahulu. Sebagian besar logam berat dalam konsentrasi yang tinggi berbahaya bagi lingkungan (air, tanah, dan udara)

Logam berat yang banyak ditemukan di lingkungan diantaranya adalah logam tembaga (Cu) dan kadmium (Cd). Keberadaan logam $\mathrm{Cu}$ dan
Cd dalam lingkungan dapat berasal dari industri, diantaranya industri penyamakan kulit, pelapisan logam, tekstil, batu baterai, dan peleburan logam [2]. Logam $\mathrm{Cu}$ dan $\mathrm{Cd}$ apabila terhirup melalui saluran pernapasan dan pencernaan manusia, maka akan menimbulkan efek bagi kesehatan. Efek yang ditimbulkan akibat terpapar oleh debu atau uap logam $\mathrm{Cu}$ dan $\mathrm{Cd}$ diantaranya terjadinya gangguan pernafasan, dan dalam jangka waktu yang Panjang dapat terakumulasi pada organ hati dan ginjal [3].

Untuk menurunkan konsentrasi dan menanggulangi pencemaran logam berat di lingkungan perairan, dapat dilakukan dengan berbagai metode baik secara fisika maupun secara kimia seperti pengendapan, pertukaran ion, filtrasi, osmosis balik, dan juga adsorpsi menggunakan 
adsorben sintetik. Metode-metode tersebut dinilai kurang efektif karena membutuhkan biaya yang relatif tinggi [4]. Dibandingkan dengan beberapa metode tersebut, Teknik adsorpsi merupakan metode yang paling umum dipakai karena lebih sederhana dan ekonomis. Salah satu adsorben yang dapat digunakan untuk menyerap logam berat adalah limbah tulang hewan, seperti pengunaan arang tulang hewan sebagai adsorben logam $\mathrm{Cr}$ berbiaya murah [5] dan adsorpsi logam Zn dengan menggunakan bubuk tulang ikan [6].

Dalam keseharian, tulang ayam merupakan limbah atau sisa makanan yang pemanfaatannya masih minim. Secara kimia komposisi tulang utamanya mengandung kira-kira $85 \%$ mineral adalah kalsium fosfat, $14 \%$ kalsium karbonat dan $1 \%$ magnesium [5]. Oleh karena itu, serbuk tulang ayam memiliki potensi sebagai adsorben untuk menyerap ion logam berat di lingkungan perariran, pemanfaatan ini memberikan dampak positif terhadap penanggulangannya sebagai sampah mengingat bahwa konsumsi daging ayam di restoran-restoran umum atau cepat saji serta dalam industri katering cukup besar serta dapat menjadi solusi untuk mengurangi pencemaran lingkungan. Di samping itu dari sisi ekonomi, tulang ayam ini masih rendah nilainya.

Pada penelitian ini dipelajari kemampuan arang aktif dari limbah tulang ayam sebagai material penyerap ion logam $\mathrm{Cu}$ dan $\mathrm{Cd}$. Optimasi penyerapan logam $\mathrm{Cu}$ dan $\mathrm{Cd}$ oleh arang aktif diuji dengan melakukan variasi waktu kontak, konsentrasi larutan dan variasi ukuran partikel dari arang aktif. Karakterisasi dari arang aktif yang dihasilkan akan dilakukan dengan pengujian Fourier Transform Infra Red (FTIR) untuk mengetahui gugus fungsi yang terdapat pada arang aktif tersebut dan pengujian dengan Scanning Electron Microscope (SEM) untuk mengetahui struktur pori.

\section{EKSPERIMEN}

\section{Material}

Bahan-bahan yang akan digunakan dalam penelitian ini adalah limbah tulang ayam, aqua DM, aquadest, larutan Cd 1000 ppm, $\mathrm{HCl}$ 2M, dan kertas saring Whatman (no. 42).

Alat-alat yang akan digunakan meliputi Gelas kimia $(50 \mathrm{~mL}, 100 \mathrm{~mL}$, dan $500 \mathrm{~mL})$, labu ukur $(50 \mathrm{~mL}, 100 \mathrm{~mL}$ dan $250 \mathrm{~mL})$, gelas ukur (50 $\mathrm{mL}$ ), pipet volume $10 \mathrm{~mL}$, cawan porselen, spatula, furnace, desikator, magnetik stirer, stirer, lumpang, pipet tetes, batang pengaduk dan ayakan (80 mesh, 100 mesh dan 120 mesh).

\section{Instrumentasi}

Instrumen yang digunakan untuk pengujian dan karakterisasi arang aktif digunakan Scanning Elektron Microscopy-Energy Dispersive X-Ray (SEM-EDX) Jeol JCM-6000, Fourier Transform Infra Red (FTIR) Cary 600 Series merek Agilent Technologies, dan Spektrofotometri Serapan Atom (SSA) 200 Series AA merek Agilent Technologies.

\section{Prosedur}

\section{Preparasi Sampel}

Tulang ayam dipisahkan bagian tulang rawannya dan dibersihkan dari daging yang masih melekat. Lalu dipecah/dibelah dan dibersihkan dari sum-sum yang melekat dari bagian dalamnya. Tulang ayam dicuci dengan detergen beberapa kali dan dibilas dengan air sebanyak tiga kali lalu dibilas dengan aquadest. Dikeringkan dengan terik matahari selama satu hari lalu digerus dan diblender. Serbuk tulang tersebut difurnace selama 60 menit pada suhu $400^{\circ} \mathrm{C}$. Selanjutnya, arang tulang ayam disimpan didalam desikator agar dingin dan kering.

Arang tulang ayam diaktifkan dengan menimbang arang sebanyak $100 \mathrm{~g}$ dimasukan ke dalam gelas kimia, kemudian ditambahkan $150 \mathrm{~mL}$ $\mathrm{HCl} 2 \mathrm{M}$. Campuran yang dihasilkan disaring dan dicuci dengan aqua DM dan dikeringkan dalam oven dalam suhu $80^{\circ} \mathrm{C}$ selama 24 jam.

\section{Pembuatan Larutan}

\section{Pembuatan deret standar}

Larutan seri standar tembaga dan kadmium dibuat dengan konsentrasi 0,2 ppm; 0,4 ppm; 0,6 ppm; 0,8 ppm, dan 1,0 ppm. Larutan kadmium 10 ppm masing- masing dipipet sebanyak $2 \mathrm{~mL}, 4 \mathrm{~mL}$, $6 \mathrm{~mL}, 8 \mathrm{~mL}$, dan $10 \mathrm{~mL}$ dimasukkan ke dalam labu ukur $100 \mathrm{~mL}$ yang berbeda. Lalu ditandabataskan dengan aqua DM dan kemudian dihomogenkan.

\section{Pembuatan kurva kalibrasi deret tembaga kadmium}

Larutan seri standar tembaga $0,2 \mathrm{ppm} ; 0,4$ ppm; 0,6 ppm; 0,8 ppm, dan 1,0 ppm diukur absorbansinya dengan menggunakan lampu katoda kadmium AAS. Perlakuan yang sama dilakukan pada larutan seri standar kadmium 0,2 ppm; 0,4 ppm; 0,6 ppm; 0,8 ppm, dan 1,0 ppm. 


\section{Karakterisasi}

Karakterisasi untuk menentukan kandungan logam menggunakan AAS, untuk menentukan gugus fungsi menggunakan FTIR, dan untuk menentukan ukuran pori menggunakan SEM.

\section{Penetuan Kondisi Optimum Adsorben}

\section{Variasi ukuran partikel arang aktif}

Arang aktif disaring dengan pengayak berukuran 80 mesh, 100 mesh, dan 120 mesh. Setelah disaring masing- masing ukuran ditimbang sebanyak 0,5 gram kemudian dimasukkan kedalam gelas kimia yang berisi $25 \mathrm{~mL}$ larutan kadmium dengan konsentrasi 0,6 ppm dan diaduk masingmasing gelas kimia selama 60 menit. Setelah diaduk larutan tersebut didekantasi dan hasil filtratnya dianalisis dengan menggunakan AAS. Selanjutnya konsentrasi ion tembaga(II) dan kadmium(II) yang diserap dihitung dan dibuat kurva daya serap terhadap ukuran pori. Diperoleh ukuran pori optimum untuk penyerapan ion tembaga(II) dan kadmium(II).

\section{Variasi konsentrasi Analit}

Larutan analit dengan variasi konsentrasi 0,6 ppm; 1,2 ppm; 1,8 ppm; 2,4 ppm dan 3,0 ppm masing- masing dipipet sebanyak $25 \mathrm{~mL}$ dan diletakkan pada gelas kimia $50 \mathrm{~mL}$. Kemudian ditambahkan 0,5 gram arang aktif dengan ukuran partikel yang memiliki adsorbansi maksimum diaduk selama 60 menit. Setelah diaduk larutan tersebut didekantasi dan hasil filtratnya dianalisis dengan menggunakan AAS. Selanjutnya konsentrasi ion tembaga(II) dan kadmium(II) yang diserap dihitung dan dibuat kurva daya serap terhadap konsentrasi awal. Diperoleh konsentrasi optimum untuk penyerapan ion tembaga(II) dan kadmium(II).

\section{Variasi waktu kontak ion kadmium}

Larutan kadmium dengan konsentrasi yang memiliki adsorbansi maksimum yang telah diperoleh dari hasil pengujian variasi konsentrasi logam kadmium diambil sebanyak $25 \mathrm{~mL}$ dan dimasukkan pada gelas kimia $50 \mathrm{~mL}$. Kemudian ditambahkan 0,5 gram arang aktif dengan ukuran partikel yang memiliki adsorbansi maksimum selanjutnya diaduk dengan variasi waktu kontak 15 menit, 30 menit, 45 menit, 60 menit dan 75 menit. Selanjutnya disaring dan hasil filtrat dianalisis menggunakan. Selanjutnya konsentrasi ion tembaga(II) dan kadmium(II) yang diserap dihitung dan dibuat kurva daya serap terhadap waktu kontak. Diperoleh waktu kontak optimum untuk penyerapan ion tembaga(II) dan kadmium(II).

\section{HASIL DAN PEMBAHASAN}

\section{Pembuatan Arang Aktif Tulang Ayam}

Tulang ayam yang digunakan pada penelitian ini adalah tulang ayam yang memiliki bagian yang keras dan dipisahkan dari sumsumnya, kemudian tulang ayam yang telah bersih dikarbonisasi.

Proses karbonisasi adalah pemecahan senyawa organik kompleks menjadi karbon sederhana. Pada proses karbonisasi, unsur-unsur selain karbon seperti hidrogen dan oksigen dibebaskan dalam bentuk gas. Suhu sangat penting pada proses karbonisasi, karena pada suhu tertentu akan menghasilkan senyawa yang berbeda seperti pada karbonisasi dengan suhu $170{ }^{\circ} \mathrm{C}$ akan menghasilkan gas $\left(\mathrm{CO}_{2}, \mathrm{CO}, \mathrm{CH}_{4}\right.$, dan $\left.\mathrm{H}_{2}\right)$, suhu $275^{\circ} \mathrm{C}$ menghasilkan senyawa ter dan metanol, dan pada suhu $400-600^{\circ} \mathrm{C}$ akan menghasilkan senyawa karbon (arang). Oleh sebab itu, pada penelitian ini menggunakan suhu $400^{\circ} \mathrm{C}$ agar tulang ayam menjadi arang. Fungsi lain dari proses pemanasan dengan suhu $400^{\circ} \mathrm{C}$ adalah untuk mendorong pengotor dan hidrokarbon hasil karbonisasi terdorong keluar dari pori arang sehingga semakin banyak volume pori arang.

Pada umumnya, arang hasil karbonisasi memiliki daya adsorpsi rendah, sehingga untuk mendapatkan arang yang mempunyai daya adsorpsi tinggi, maka dilakukan proses aktivasi. Proses aktivasi menggunakan zat aktivator yaitu larutan $\mathrm{HCl} 2 \mathrm{M}$. Setelah diaktivasi arang dibilas dengan menggunakan aqua DM untuk menghilangkan asam pada permukaan sampel. Agar dapat dipelajari juga pengaruh ukuran partikel arang tulang ayam terhadap proses penyerapan logam. Saringan yang digunakan berukuran 80 mesh, 100 mesh, dan 120 mesh.

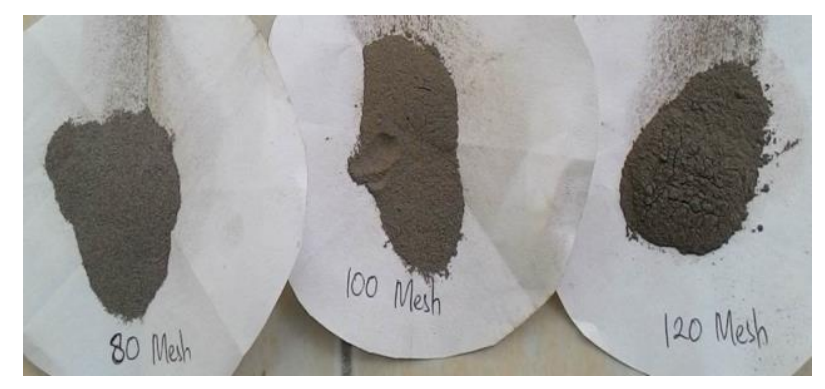

Gambar 1. Arang aktif yang telah diayak 


\section{Adsorpsi Ion Logam Kadmium dan Tembaga}

Proses adsorpsi dapat terjadi karena adanya gaya tarik antar atom atau molekul pada permukaan padatan yang tidak seimbang. Adanya gaya ini, padatan cenderung menarik molekul- molekul lain yang bersentuhan dengan permukaan padatan, baik fasa gas atau fasa larutan kedalam permukaannya. Akibatnya, konsentrasi molekul pada permukaan menjadi lebih besar daripada dalam fasa gas atau zat terlarut dalam larutan. Adsorpsi dapat terjadi pada antar fasa padat- cair, padat- gas, atau gascair. Untuk menetukan optimasi adsorben dapat dilakukan dengan berbagai proses, diantaranya: bahan penyerap, ukuran butir, derajat keasaman (pH larutan), waktu serap, dan konsentrasi.

Pengaruh Konsentrasi Awal Ion Logam Cd dan Cu terhadap Adsorpsi dengan Arang Tulang Ayam

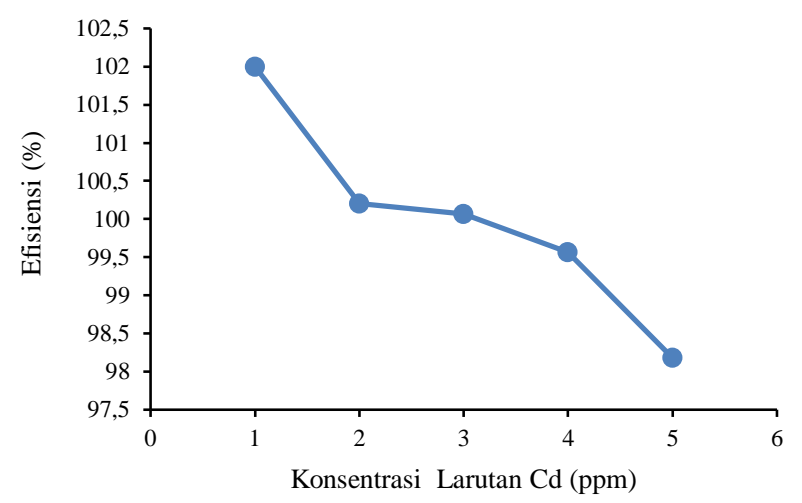

Gambar 2. Hubungan Konsentrasi Awal Cd dengan Efisiensi penyerapan

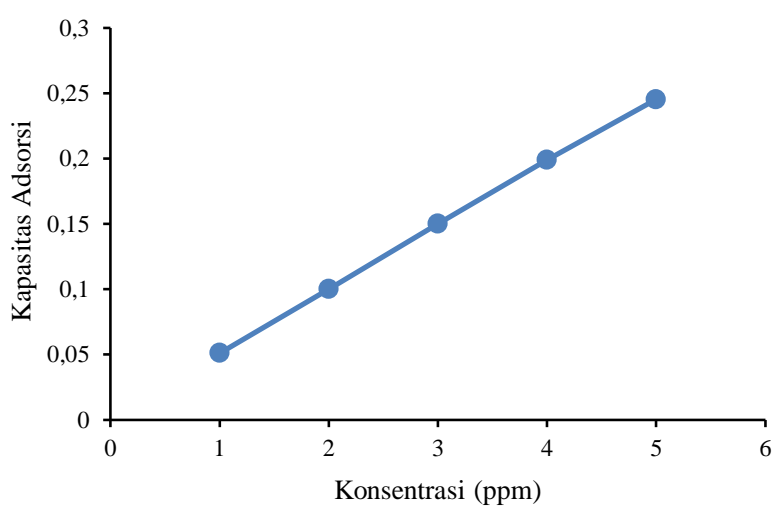

Gambar 3. Grafik Hubungan antara Konsentrasi Awal Ion Logam Cd dengan Kapasitas Adsorpsi

Dari Grafik hubungan antara konsentrasi awal ion Logam Cd dengan kapasitas adsorpsi, dapat terlihat bahwa semakin besar konsentrasi awal dari logam $\mathrm{Cd}$ maka kapasitas adsorpsi semakin meningkat. Hal ini dimungkinkan karena konsentrasi awal dari ion logam $\mathrm{Cd}$ yang digunakan terlalu rendah, sehingga kapasitas adsorpsinya belum menunjukkan nilai yang maksimum.

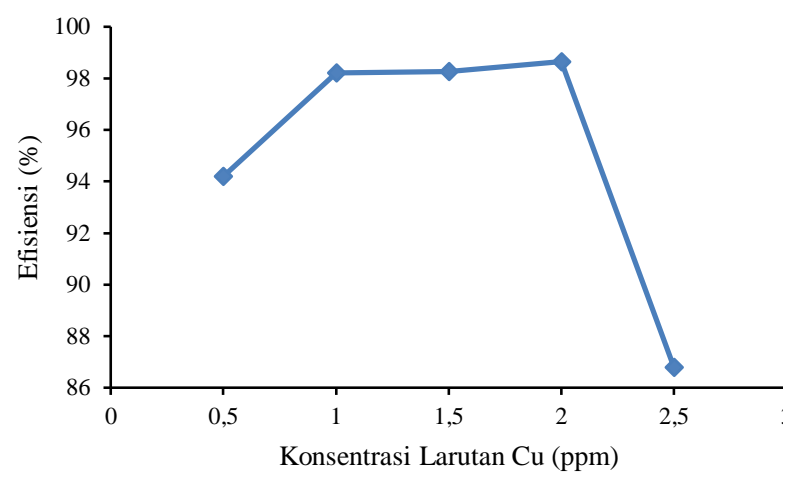

Gambar 4. Hubungan Konsentrasi Awal $\mathrm{Cu}$ dengan Daya Serap

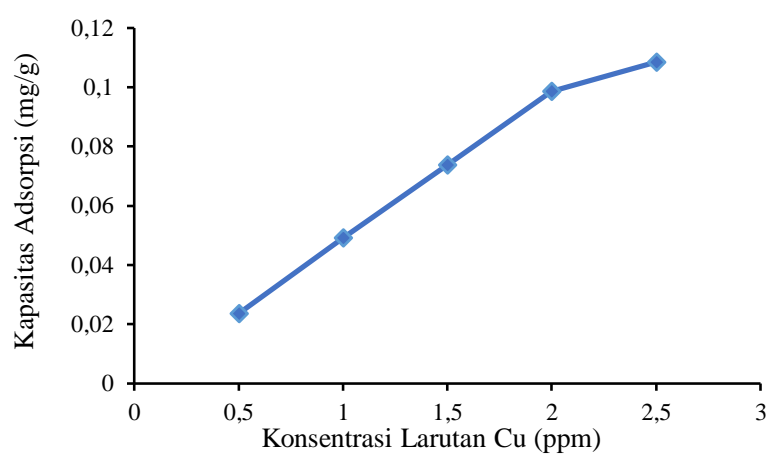

Gambar 5. Grafik Hubungan antara Konsentrasi Awal Ion Logam $\mathrm{Cu}$ dengan Kapasitas Adsorpsi

Kapasitas Adsorpsi logam $\mathrm{Cu}$ pada konsentrasi 0,5 ppm sampai dengan 2,5 ppm terus meningkat. Namun peningkatan kapasitas adsorpsi pada konsentrasi di atas 2 ppm tidak sebesar peningkatan kpasitas adsorpsi pada konsentrasi di bawah 2 ppm. Hasil ini sejalan dengan hasil dari hubungan konsentrasi awal dengan efisiensi penyerapan arang aktif, yaitu pada konsentrasi di atas $2 \mathrm{ppm}$ efisiensi penyerapan arang aktif terhadap logam $\mathrm{Cu}$ menurun.

Pengaruh Waktu kontak terhadap Adsorpsi Ion Logam Cu dan Cd pada Arang Aktif Tulang Ayam

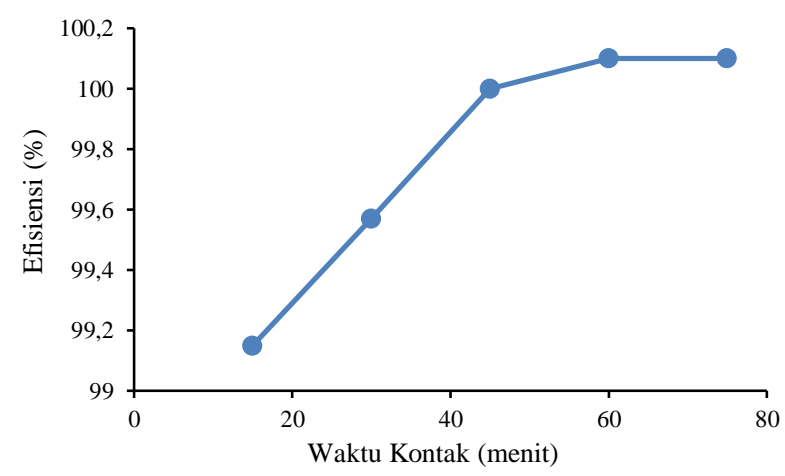

Gambar 6. Hubungan Waktu Kontak dengan Efisiensi Penyerapan Logam Cd 


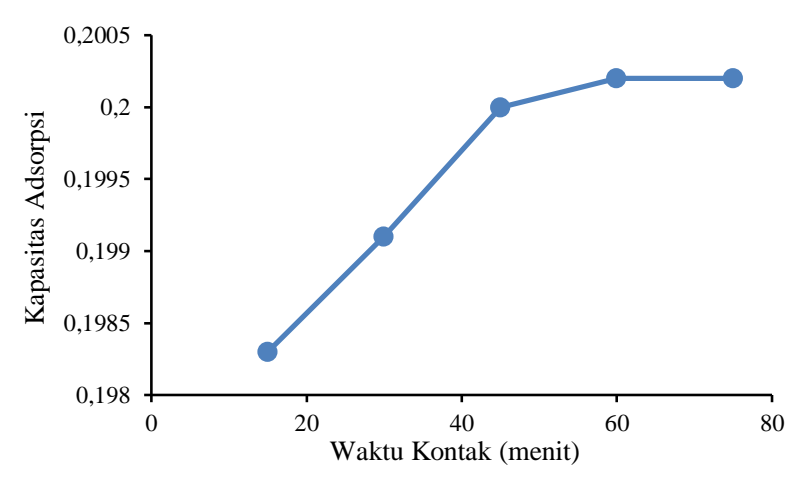

Gambar 7. Hubungan Waktu Kontak dengan Kapasitas Adsorpsi Logam Cd

Dari grafik tersebut menunjukkan bahwa semakin lama waktu kontak maka persentase ion kadmium yang terserap semakin besar. Penyerapan optimum terjadi pada menit ke 60 dan 75 dengan $\%$ ion kadmium yang terserap sebanyak $100,1 \%$. Semakin lama waktu kontak maka efisiensi penyerapan logam $\mathrm{Cd}$ pada arang aktif semakin meningkat. Namun setelah menit ke-45 efisiensi penyerapan tidak berubah lagi, dikarenakan pada menit ke-45 seluruh logam Cd telah terserap oleh arang aktif. Hubungan waktu kontak dengan efisiensi penyerapan logam $\mathrm{Cd}$ mempunyai trend yang sama dengan grafik hubungan waktu kontak dengan kapasitas adsorpsi.

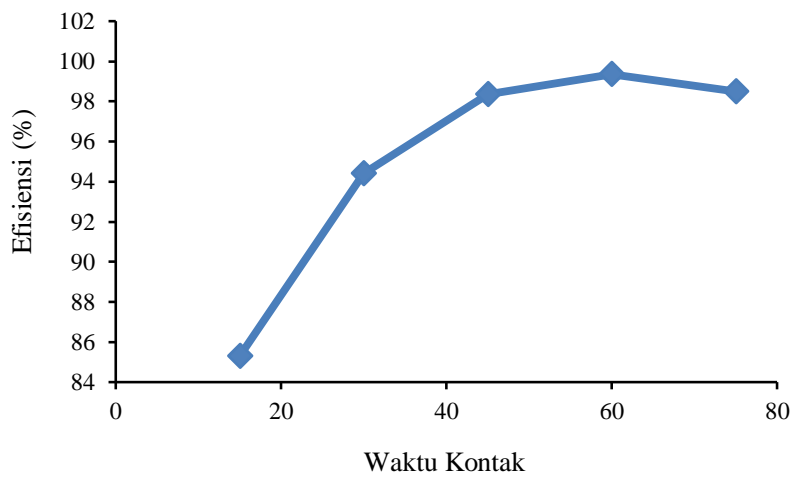

Gambar 8. Hubungan Waktu Kontak dengan Efisiensi Penyerapan Logam $\mathrm{Cu}$

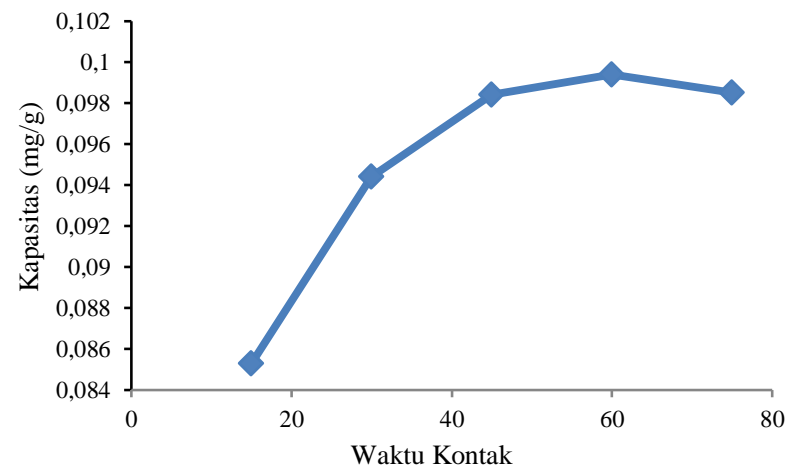

Gambar 9. Hubungan Waktu Kontak dengan Kapasitas Adsorpsi Logam $\mathrm{Cu}$
Semakin lama waktu kontak maka efisiensi penyerapan logam $\mathrm{Cu}$ pada arang aktif semakin meningkat. Namun setelah menit ke-60 efisiensi penyerapan tidak berubah lagi, dikarenakan pada menit ke-60 seluruh logam $\mathrm{Cu}$ telah terserap oleh arang aktif. Hubungan waktu kontak dengan efisiensi penyerapan logam $\mathrm{Cu}$ mempunyai trend yang sama dengan grafik hubungan waktu kontak dengan kapasitas adsorpsi.

Pengaruh Ukuran Partikel Arang Aktif terhadap Efisiensi Penyerapan dan Kapasitas Adsorpsi Ion Logam Kadmium dan Tembaga

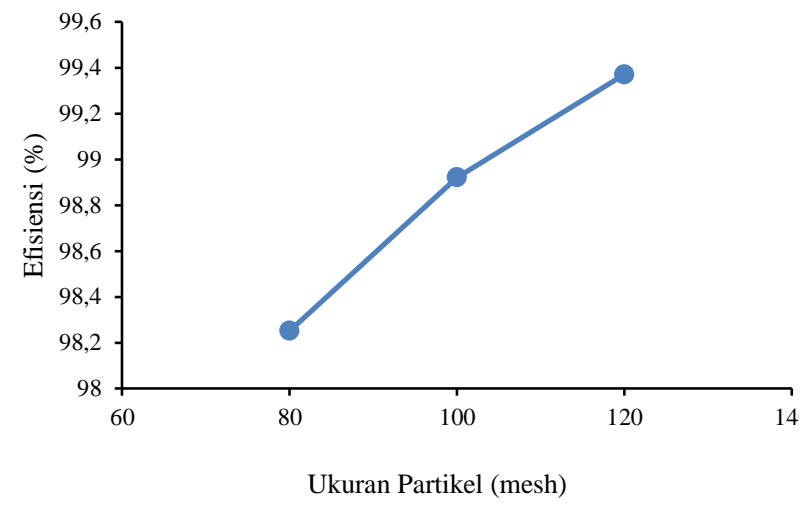

Gambar 10. Hubungan antara Ukuran Partikel dengan Efisiensi Penyerapan Logam Cd

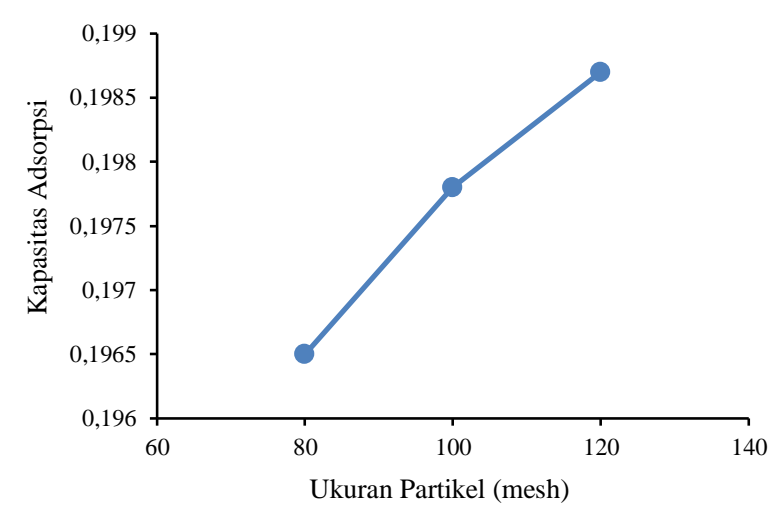

Gambar 11. Hubungan antara Ukuran Partikel dengan Kapasitas Adsorpsi Logam Cd

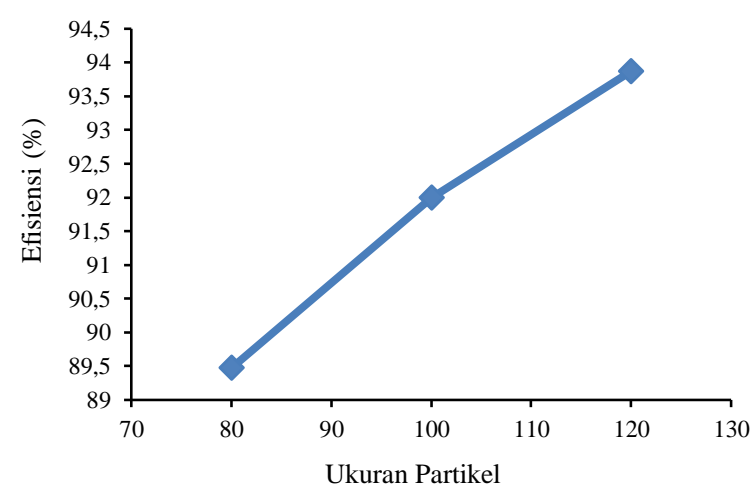

Gambar 12. Hubungan antara Ukuran Partikel dengan Kapasitas Adsorpsi Logam Cd 


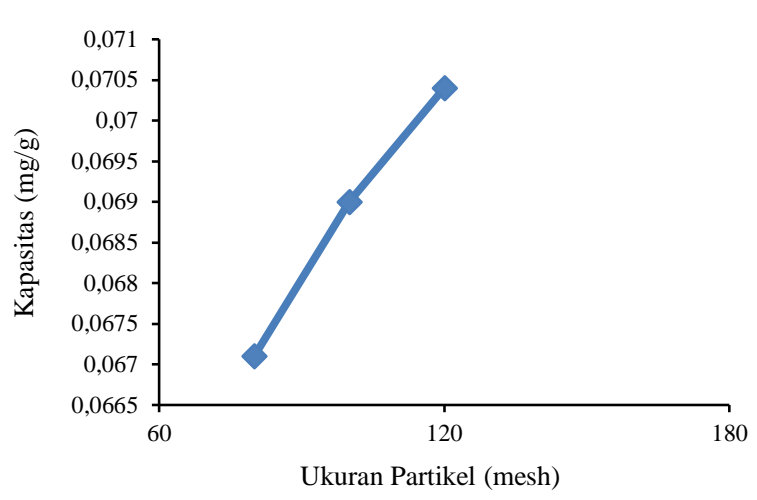

Gambar 13. Hubungan antara Ukuran Partikel dengan Kapasitas Adsorpsi Logam Cd

Dari grafik tersebut menunjukkan bahwa semakin besar ukuran partikel maka persentase ion kadmium yang terserap semakin besar. Penyerapan optimum terjadi pada ukuran partikel 120 mesh dengan \% ion kadmium yang terserap sebanyak 99,37\%. Jika pengaruh ukuran partikel terhadap efisiensi penyerapan dibandingkan dengan pengaruh ukuran partikel terhadap kapasitas adsorpsi ion logam $\mathrm{Cd}$, maka kedua grafik akan memiliki trend yang sama.

Pada adsorpsi ion logam $\mathrm{Cu}$, pengaruh ukuran partikel terhadap efisiensi penyerapan dan kapasitas adsorpsi memberikan hasil yang sama dengan pengaruh ukuran partikel terhadap efisiensi penyerapan dan kapasitas adsorpsi ion logam $\mathrm{Cd}$. Yaitu semakin besar ukuran partikel maka efisiensi penyerapan dan kapasitas adsorpsi semakin besar. Efisiensi maksimum dari penyerapan logam $\mathrm{Cu}$ pada arang aktif tulang ayam memberikan hasil 93,87\% dengan kapasitas adsorpsi maksimum $0,0704 \mathrm{mg} / \mathrm{g}$.

\section{Karakterisasi Arang Aktif Tulang Ayam}

\section{Analisis FTIR}

Analisis FTIR bertujuan untuk menganalisis senyawa dan gugus fungsi senyawa di dalam arang aktif tulang ayam dalam bentuk spektrum. Spektrum IR arang aktif tulang ayam dapat dilihat pada Tabel 1 dan Gambar 14.

Tabel 1. Hasil Pengujian Menggunakan FTIR

\begin{tabular}{cc}
\hline Gugus & Bilangan Gelombang \\
\hline $\mathrm{Ca}^{2+}$ & $500-610 \mathrm{~cm}^{-1}$ \\
$-\mathrm{PO}_{4}{ }^{3-}$ & $1000-1100 \mathrm{~cm}^{-1}$ \\
$-\mathrm{CO}_{3}$ & $961,56 \mathrm{~cm}^{-1}$ \\
protein dan kolagen & $1400-1700 \mathrm{~cm}^{-1}$ \\
$-\mathrm{C}=\mathrm{O}, \mathrm{C}=\mathrm{C}, \mathrm{C}=\mathrm{N},-\mathrm{C}-\mathrm{H}-$ & $2943-2987 \mathrm{~cm}^{-1}$ \\
\hline
\end{tabular}

Dari hasil analisis arang aktif menggunakan alat Spektrofotometer Inframerah, didapat spektra arang aktif tulang ayam yang mengindikasikan adanya gugus $\mathrm{Ca}^{2+},-\mathrm{PO}_{4}{ }^{3-}$ pada bilangan gelombang 500-610 $\mathrm{cm}^{-1}$ dan 1000-1100 $\mathrm{cm}^{-1}$. Gugus-gugus tersebut merupakan penyusun senyawa kristal heksagonal kalsium fospat hidroksiapatit $\left(\mathrm{Ca}_{10}\left(\mathrm{PO}_{4}\right)_{6}(\mathrm{OH})_{2}\right)$ yang mempunyai permukaan berpori. Pada bilangan gelombang pada $961,56 \mathrm{~cm}^{-1}$ yang mengindikasikan adanya gugus $\mathrm{CO}_{3}$. Pada bilangan gelombang $1400-1700 \mathrm{~cm}^{-1}$ adanya gugus protein dan collagen $-\mathrm{C}=\mathrm{O}, \mathrm{C}=\mathrm{C}$, $\mathrm{C}=\mathrm{N}$, pada spektra arang tulang ayam muncul gugus - $\mathrm{C}-\mathrm{H}$ - hidrokarbon stretching pada bilangan gelombang 2943-2987 $\mathrm{cm}^{-1}$.

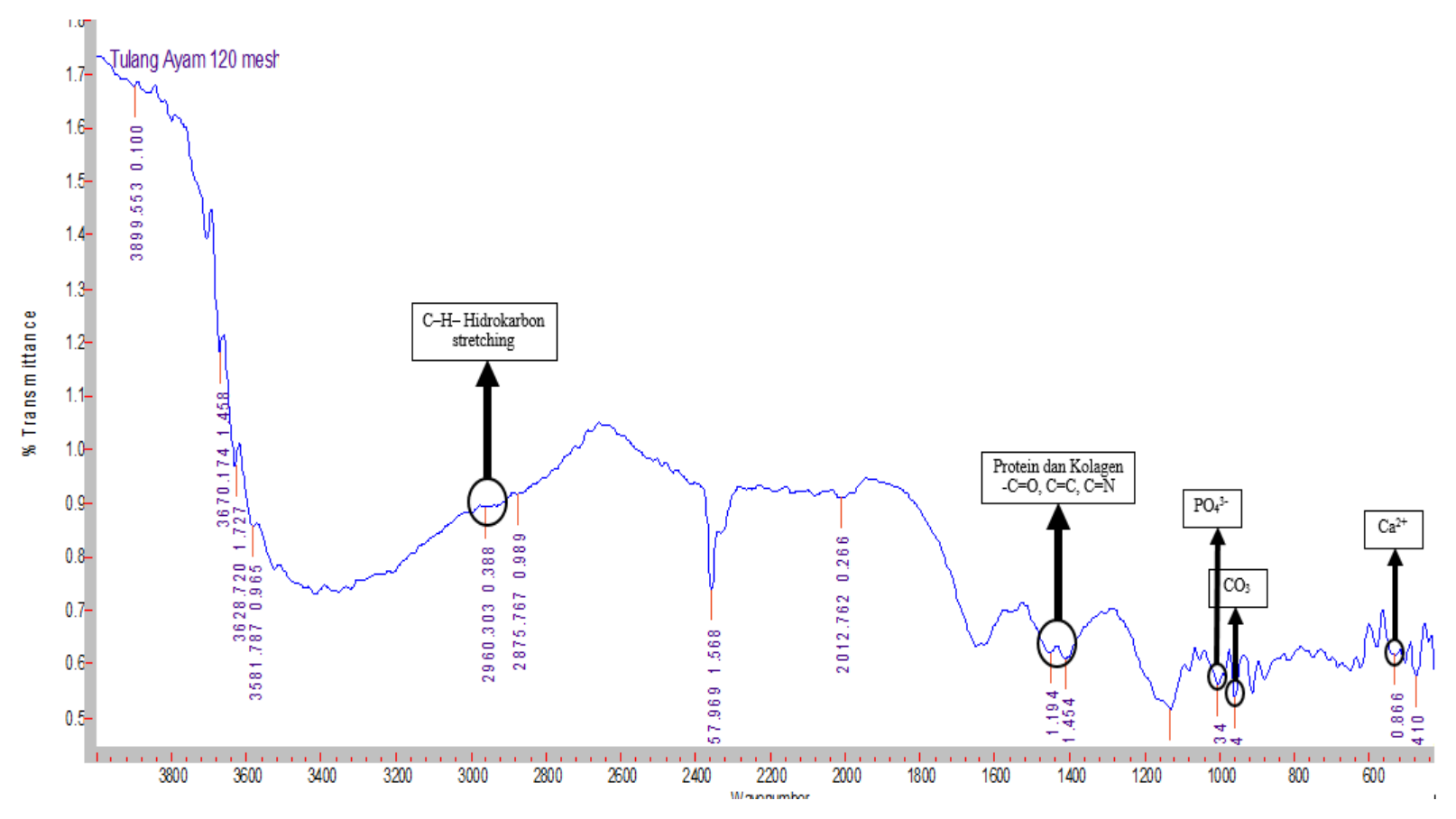

Gambar 14. Spektrum FTIR Arang Tulang Ayam 


\section{Analisis SEM}

Ion logam kadmium dan tembaga diperkirakan dapat teradsorpsi ke dalam pori-pori material kalsium hidroksiapatit tulang ayam. Sehingga pada saat diaduk dengan stirer ion logam tembaga dan kadmium ikut teradsorpsi dalam poripori material kalsium hidroksiapatit. Untuk mempelajari adsorpsi ion logam terhadap arang aktif, maka dilakukan studi terhadap morfologi arang aktif melalui foto SEM terhadap serbuk tulang ayam sebelum dan sesudah perlakuan. Hasil foto SEM ditunjukkan pada Gambar 15 berikut:

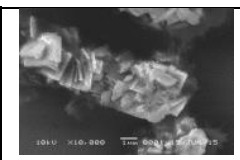

(a)

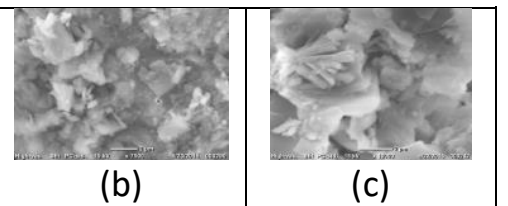

(b)
5. Kapasitas adsorpsi arang aktif tulang ayam terhadap ion logam tembaga dan kadmium meningkat dengan meningkatnya konsentrasi awal ion logam cadmium, waktu kontak, dan ukuran partikel.

\section{UCAPAN TERIMA KASIH}

Penulis mengucapkan terima kasih kepada Laboratorium Fisika UIN SGD Bandung atas diskusi interpretasi Scanning Elektron MicroscopyEnergy Dispersive X-Ray (SEM-EDX); Laboratorium Kimia UIN SGD Bandung atas diskusi dan analisis Fourier Transform Infra Red (FTIR), dan Spektrofotometri Serapan Atom (SSA).

\section{REFERENSI}

[1] Anis S and Gusrizal , "Pengaruh $\mathrm{pH}$ dan Penentuan Kapasitas Adsorpsi Logam Berat pada Biomassa Eceng Gondok (Eichhornia crassipes)," Indo. J. Chem, vol. 6, no. 1, pp. 56-60, 2006.

[2] James Moore and Ramamoorthy , "Organics Chemicals in Natural Water, Applied Monitoring and Impact Assesment," Journal Spinger-Verlag, 1984.

[3] H Palar, Pencemaran dan Toksikologi Logam Berat. Jakarta, Indonesia: Rineka Cipta, 1994.

[4] Lelifajri , "Adsorpsi Ion Logam Cu (II) Menggunakan Lignin dari Limbah Serbuk Kayu Gergaji," FMIPA Universitas Syiah Kuala, Banda Aceh, 2010.

[5] Agarwal, A., \& Gupta, P. K. (2015). Adsorption study of $\mathrm{Cr}$ (II) from aqueous solution using animal bone charcoal as low cost adsorbent. International Journal of Engineering Technology, Management and Applied Sciences, 3(1), 151-163.

[6] Lim, H.K., Teng, T.T., Ibrahim, M.H., Ahmad, A., \& Chee, H.T. (2012). Adsorption and removal of Zinc (II) from aqueous solution using powdered fish bones. APCBEE Procedia, 1, 96-102. 